\title{
Plasminogen Activator Inhibitor Activity in Bacterial Infection
}

\author{
J. A. Páramo, F. J. Fernández Diaz, and E. Rocha \\ From the Hematology Service, University Clinic, University of Navarra, Pamplona, Spain
}

\section{Key words}

Plasminogen activator inhibitor - Bacterial infection - Disseminated intravascular coagulation

\section{Summary}

It has been experimentally shown that endotoxin induces a marked increase in the levels of a fast-acting inhibitor of plasminogen activator (PAI). The plasma PAI activity and tissuetype plasminogen activator ( $\mathrm{t}-\mathrm{PA}$ ) concentrations were measured in 61 patients with human septicaemia and results were compared with those observed in healthy controls. There was a markedly significant increase of PAI in plasma and platelet extracts of patients with septicaemia as compared to controls $(\mathrm{p}<0.0001)$. No correlation between PAI and endotoxin concentration was observed. Fibrin autography of plasma samples confirmed that activator inhibition was associated with the formation of an enzyme-inhibitor complex. t-PA activity was similar in patients and controls, whereas t-PA Ag showed a significant increase in patients $(\mathrm{p}<0.0001)$. A significant inverse correlation between t-PA activity and PAI was observed $(\mathrm{p}<0.05)$. PAI activity was higher in patients with positive blood cultures $(p<0.0001)$ and gram-negative septicaemia $(\mathrm{p}<0.0001)$. There was also a significant increase of PAI levels in patients with disseminated intravascular coagulation (DIC) as compared with patients without DIC $(\mathrm{p}<0.001)$. We conclude that there is a marked increase of PAI in patients with sepsis. Increased PAI activity may contribute to the pathogenesis of DIC associated with septicaemia.

\section{Introduction}

Disorders of the hemostatic system leading to disseminated intravascular coagulation (DIC) can be induced in animal species by injection of endotoxin, a cell wall constituent of gram-negative bacteria (1). Similar changes can be observed in human septicaemia (2). It appears that endotoxin has a marked effect on endothelial cell function. Endothelial cells are known to play an important role in fibrinolysis by modulating the synthesis of plasminogen activators and inhibitors (3). Deficient fibrinolysis may contribute to the precipitation of fibrin within blood vessels (4).

Plasminogen activator inhibitors (PAI) have been identified in plasma (5-9), platelets (10), placenta (11) and in the conditioned medium of endothelial cells (12-17). They seem to play an important role in different clinical conditions related to deficient fibrinolysis associated with thrombotic phenomena (18). Recently, Colucci et al. (19) have reported a marked increase in the concentration of PAI in a small series of patients with septicaemia.

Correspondence to: E. Rocha, MD, Servicio de Hematología, Clínica Universitaria, Apartado 192, 31080-Pamplona, Spain
The present study was undertaken to investigate the plasminogen activator inhibitor activity in the blood of patients with bacterial infection. The possible role of this inhibitor in the pathogenesis of DIC associated with sepsis was also studied.

\section{Patients and Methods}

\section{Patients}

Sixty-one patients with local and disseminated bacterial infections were studied. There were 41 males, 20 females and the mean age was $51 \pm 17$ years (range 15-79). The diagnosis of septicaemia was established in 32 patients based on the typical clinical picture, repeated temperature over $38.5^{\circ} \mathrm{C}$ and positive blood cultures. Twenty-six patients developed gramnegative septicaemia. Bacteriological studies identified E. coli (13), Salmonella (6), Serratia (2), Enterobacter (2), Pseudomonas (1), Neisseria (1) and Proteus (1). Six patients presented with gram-positive septicaemia. Bacteriological identification showed Staphylococcus (3), Streptococcus (2) and Listeria (1). The remaining 29 patients presented with a localized site of infection and negative blood cultures.

A control group consisted of 30 age and sex-matched healthy subjects.

\section{Blood Samples}

Blood from the antecubital vein was collected into 0.1 vol trisodium citrate (final concentration $0.011 \mathrm{M}$ ) and immediately cooled on ice. All samples were taken before antibiotic therapy was started and, when possible, in the moining. Platelet-rich plasma (PRP) was obtained by 10 min centrifugation at $200 \mathrm{~g}$ at room temperature. Platelet-poor plasma (PPP) was obtained by further centrifugation for $15 \mathrm{~min}$ at 2,500 $\mathrm{g}$ and $4^{\circ} \mathrm{C}$, and stored at $-70^{\circ} \mathrm{C}$. The PRP was pipetted off and platelets were adjusted to $500,000 / \mathrm{mm}^{3}$. Subsequently PRP was centrifuged at $20^{\circ} \mathrm{C}$ and $2,400 \mathrm{~g}$ for $30 \mathrm{~min}$ and the pellet resuspended in $0.05 \mathrm{M}$ Tris $\mathrm{HCl}, 0.1 \mathrm{M}$ $\mathrm{NaCl}, 3 \mathrm{mM}$ EDTA, pH 7.3 (final volume equal to the original volume of the PRP). Platelets were extracted by adding $1 / 10$ volume of $10 \%$ Triton $\mathrm{X}-100$. Platelet extracts were stored at $-70^{\circ} \mathrm{C}$ until use.

\section{Reagents}

Plasminogen-rich human fibrinogen was purchased from Kabi Diagnostica (Sweden); fibrinogen fragment was obtained by digestion of fibrinogen with CNBr as described by Verheijen et al. (20). Two-chain melanoma cell t-PA with a specific activity of $100,000 \mathrm{IU} / \mathrm{mg}$ was kindly provided by Dr. Collen (Leuven, Belgium). Chromogenic substrates S-2251 and S-2423 were obtained from Kabi Diagnostica (Sweden).

\section{Tissue-Type Plasminogen Activator ( $t-P A)$ Activity}

t-PA activity was determined by spectrophotometric assay (20). Diluted euglobulin fraction was mixed in a microtiter plate to a final volume of $200 \mu \mathrm{l}$ with $0.02 \mathrm{M}$ Tris $\mathrm{HCl}, \mathrm{pH} 7.5,0.1 \%$ Tween 80 , $0.30 \mathrm{mmol} / \mathrm{l} \mathrm{S}-2251,0.13 \mu \mathrm{mol} / \mathrm{l}$ human plasminogen and $0.12 \mathrm{mg} / \mathrm{ml}$ $\mathrm{CNBr}$ fibrinogen fragments. The plate was incubated at $37^{\circ} \mathrm{C}$ and the change in absorbance at $405 \mathrm{~nm}$ was measured with a titertek multiskan spectrophotometer (Flow Laboratories, Inc., McLean, VA).

\section{Determination of $t-P A$ Antigen $(t-P A A g)$}

t-PA Ag was performed by using t-PA ELISA kit from Biopool AB (Umeå, Sweden). The plasma was not acidified. 
Table 1 Plasma PAI activity in patients and controls. Mean $\pm \mathrm{SD}$ is reported

\begin{tabular}{llr}
\hline & $\begin{array}{l}\text { Number of } \\
\text { patients }\end{array}$ & $\begin{array}{l}\text { PAI activity } \\
(\mathrm{U} / \mathrm{ml})\end{array}$ \\
\hline -Control group & 30 & $0.85 \pm 0.77$ \\
-Total patient group & 61 & $7.05 \pm 6.96$ \\
Local infection & 29 & $3.39 \pm 6.93$ \\
Positive blood cultures & 32 & $10.37 \pm 5.14$ \\
Gram-negative septicaemia & 26 & $12.11 \pm 3.77$ \\
Gram-positive septicaemia & 6 & $2.81 \pm 2.92$ \\
DIC & 9 & $13.54 \pm 9.84$ \\
\hline
\end{tabular}

\section{Determination of PAI Activity}

PAI was measured as previously described (21). Human t-PA (2 IU/ml final concentration) was incubated for $1 \mathrm{~min}$ at $37^{\circ} \mathrm{C}$ with plasma or platelet extracts diluted four-fold or more in $0.02 \mathrm{M}$ Tris $\mathrm{HCl}, 0.1 \mathrm{M} \mathrm{NaCl}$ $0.01 \%$ Triton $\mathrm{X}-100 \mathrm{pH} 8.8$. The samples were acidified with $0.16 \mathrm{M} \mathrm{HCl}$ and incubated $10 \mathrm{~min}$ at room temperature. The $\mathrm{pH}$ was adjusted with $0.16 \mathrm{M} \mathrm{NaOH}$. Remaining t-PA activity was measured by spectrophotometric assay as described above. Inhibitor activity was expressed in units of plasminogen activator inhibited per $\mathrm{ml}$.

\section{Analysis of Plasminogen Activator-Inhibitor Complexes by SDS-PAGE} and Fibrin-Enzymography

Fibrin autography was performed essentially as described by Loskutoff and Mussoni (22). Plasma samples to be analyzed by SDS-PAGE were first incubated at $37^{\circ} \mathrm{C}$ for $5 \mathrm{~min}$ in the presence of t-PA $(50 \mathrm{IU} / \mathrm{ml}$ final concentration). Fifty $\mu \mathrm{l}$ of $1 / 20$ diluted sample was then subjected to electrophoresis in sodium dodecylsulfate on an $8 \%$ polyacrylamide gel that was then washed for $60 \mathrm{~min}$ in $2.5 \%$ Triton X-100. Gels to be

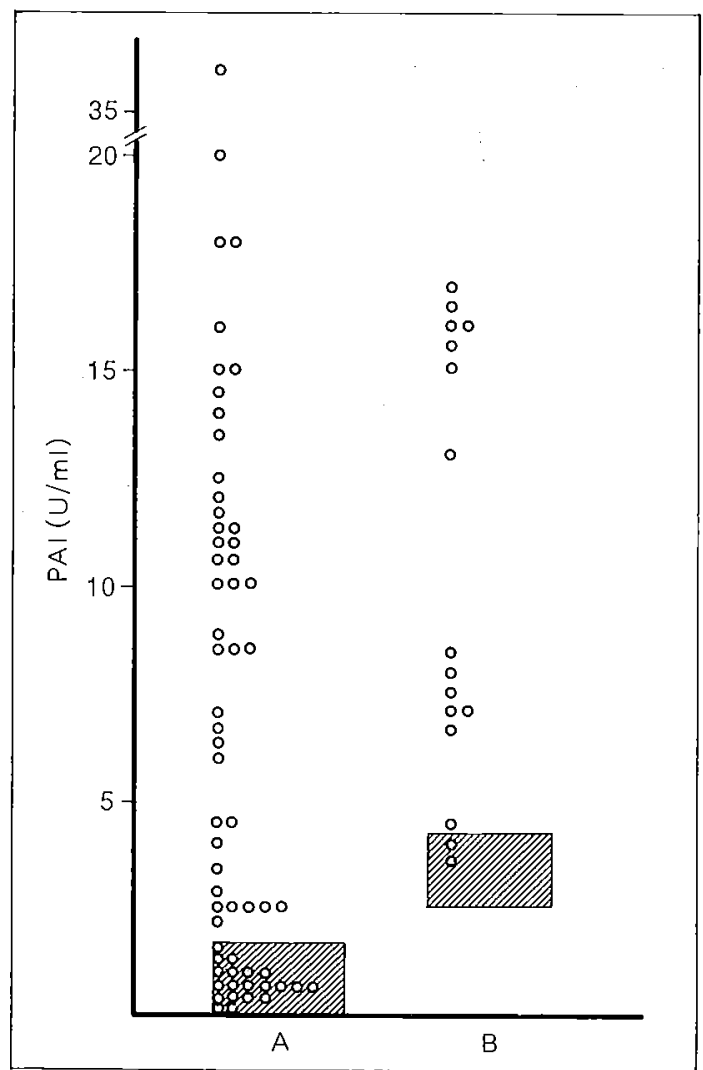

Fig. 1 Distribution of PAI in plasma samples (A) and platelet extracts (B) from patients with bacterial infection. The shaded areas represent the normal values of healthy matched controls (mean \pm SD) analyzed were applied to the surface of a freshly formed fibrin agar gel containing in final concentrations: agarose $2 \%$, plasminogen $25 \mu \mathrm{g} / \mathrm{ml}$, fibrinogen $10 \mathrm{mg} / \mathrm{ml}$ and thrombin $(0.5 \mathrm{U} / \mathrm{ml})$. Gels were incubated at $37^{\circ} \mathrm{C}$ for $16 \mathrm{~h}$ stained with Coomassie brilliant blue, destained in $30 \%$ methanol and $10 \%$ acctic acid and photographed.

\section{Endotoxin Concentration in Plasma}

Endotoxin concentration was determined by using a limulus lysate chromogenic peptide substrate (Coatest Endotoxin, Kabi Diagnostica, Sweden).

\section{Statistical Analysis}

The data were evaluated using Student's t-test for comparison of means and S.D.

\section{Results}

Sixty-one patients with local and disseminated bacterial infection were studied. Mean plasma endotoxin concentration in patients was $1.77 \pm 2.25 \mathrm{ng} / \mathrm{ml}$ (not detectable in controls). The distribution of PAI concentrations in the studied groups is shown in Fig. 1 . There was a markedly significant increase $(\mathrm{p}<0.0001)$ in the plasma levels of PAI in patients $(7.05 \pm 6.96 \mathrm{U} / \mathrm{ml})$ as compared to controls $(0.85 \pm 0.77 \mathrm{U} / \mathrm{ml})$. The PAI levels in platelet extracts (determined in 16 patients) were significantly higher $(p<0.0001)$ in patients $(10.27 \pm 4.90 \mathrm{U} / \mathrm{ml})$ than those observed in healthy individuals $(3.34 \pm 0.81 \mathrm{U} / \mathrm{ml})$. No correlation between endotoxin concentration and plasma PAI activity was found $(r=-0.030)$.

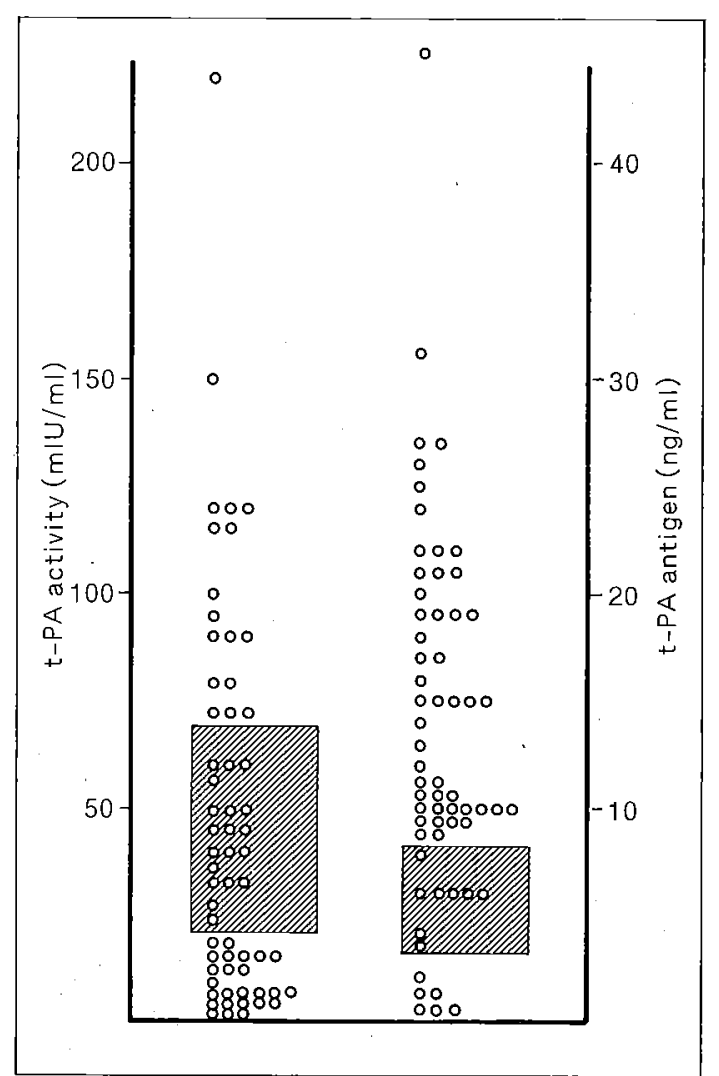

Fig. 2 Distribution of t-PA activity and t-PA $\mathrm{Ag}$ in patients with bacterial infection. The shaded areas represent the normal values of healthy matched controls (mean $\pm S D$ ). Significant differences for $t$-PA Ag $(p<0.0001)$ whereas no differences for t-PA activity were observed 

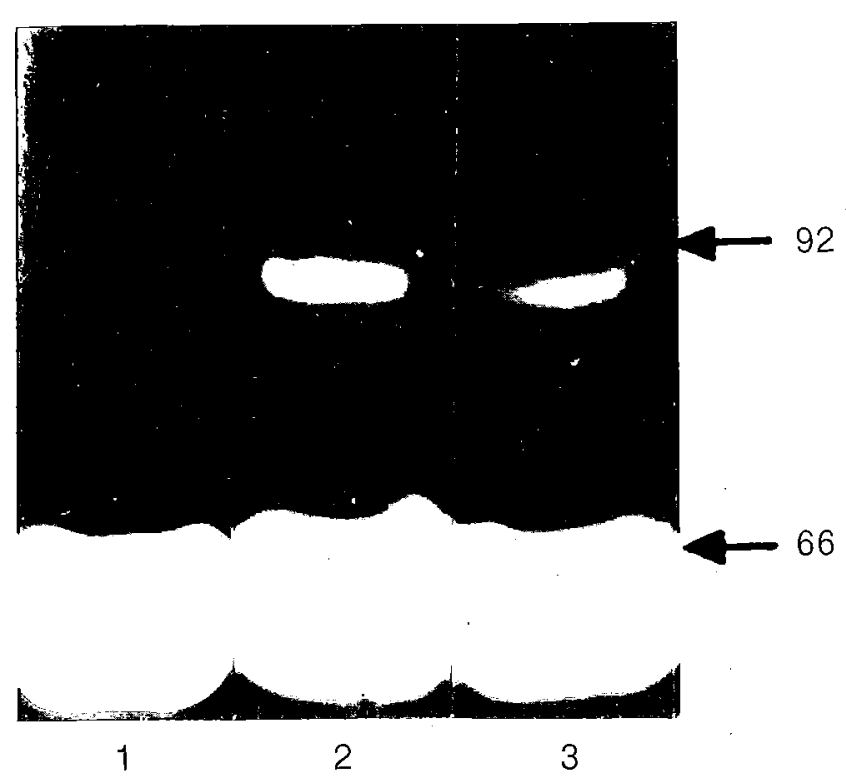

Fig. 3 Fibrin autography of plasma samples from a normal subject (1) and from two patients ( 2 and 3 ) with septicaemia and high inhibitor levels $(>20 \mathrm{U} / \mathrm{ml})$. Molecular weights are shown as $M_{r} \times 10^{-3}$

As shown in Fig. 2, t-PA activity in patients $(46.49 \pm 45.57 \mathrm{mIU} / \mathrm{ml})$ was not significantly different from that observed in healthy subjects $(45.47 \pm 24.20 \mathrm{mIU} / \mathrm{ml})$. However, t-PA Ag levels were significantly higher $(\mathrm{p}<0.0001)$ in patients $(13.65 \pm 8.50 \mathrm{ng} / \mathrm{ml})$ than in controls $(5.63 \pm 2.52 \mathrm{ng} / \mathrm{ml})$. A slightly significant inverse correlation $(\mathrm{r}=0.26, \quad \mathrm{p}<0.05)$ between t-PA activity and plasma PAI levels was observed.

Fibrin autography of plasma samples supplemented with purified t-PA $(50 \mathrm{IU} / \mathrm{ml})$ confirmed that activator inhibition was associated with the formation of an enzyme-inhibitor complex with an apparent molecular weight of $100 \mathrm{kDa}$ (Fig. 3).

Thirty-two out of 61 patients showed positive blood cultures. The plasma levels of PAI (Table 1) in these patients $(10.37 \pm 5.14 \mathrm{U} / \mathrm{ml})$ were significantly higher $(\mathrm{p}<0.0001)$ than those observed in 29 patients with local infection and negative blood cultures $(3.39 \pm 6.93 \mathrm{U} / \mathrm{ml})$.

In 26 out of 32 patients with positive blood cultures, bacteriological studies identified gram-negative bacteria. Plasma PAI levels were significantly increased $(\mathrm{p}<0.0001)$ in these patients $(12.11 \pm 3.77 \mathrm{U} / \mathrm{ml})$ as compared to those observed in 6 patients with gram-positive septicaemia $(2.81 \pm 2.92 \mathrm{U} / \mathrm{ml})$.

Nine out of 61 patients studied showed DIC diagnosed on the basis of thrombocytopenia, low fibrinogen and antithrombin III levels, presence of fibrin monomers and increase of fibrinogen degradation products. Plasma levels of PAI in these patients $(13.54 \pm 9.84 \mathrm{U} / \mathrm{ml})$ were significantly increased $(\mathrm{p}<0.001)$ as compared with PAI concentrations in the remaining 52 patients without DIC $(5.93 \pm 5.75 \mathrm{U} / \mathrm{ml})$.

\section{Discussion}

The current study was undertaken to determine whether human bacterial infection induces changes in PAI concentration. Our results confirm that infections, especially septicaemia, are associated with a marked increase in plasma PAI activity. The relevance of PAI in sepsis can be inferred from the relationship between high inhibitor levels and the different clinical conditions related to thrombotic phenomena (23-25).

That the inhibitor activity measured by the functional assay is due to $\mathrm{t}-\mathrm{PA}$ inhibition is demonstrated by the complex formation observed on fibrin-enzymography. This inhibitor seems to be of endothelial type according to experimental observations in rabbits and endothelial cells $(19,26,27)$. The induced plasma PAI and the endothelial cell-derived PAI are closely related with regard to molecular weight, inhibition constant and immunochemical characteristics (28-31).

Platelet PAI activity was also significantly higher in patients as compared to controls. Immunological studies have suggested that PAI in plasma and platelets are immunologically related to each other $(30,31)$ buth they represent two different compartments of PAI activity (32). It seems improbable that platelets would contribute to the PAI activity of plasma under physiological conditions (33). However, platelet stimulation in vivo, such as that occurring in septicaemia may result in significantly increased levels of PAI. Platelets might contribute to the inhibition of fibrinolysis, protecting the blood clot against premature lysis (18).

One interesting finding was the lack of correlation between PAI activity and endotoxin concentration observed in the patient group, which is in agreement with experimental observations in rabbits (19) and endothelial cells (26), showing that a minimum dose of endotoxin is able to induce a marked inhibitor response.

In contrast to normal t-PA activity, t-PA Ag was elevated in patients as compared to controls. Increased t-PA Ag levels with normal t-PA activity as observed in our patients can be explained by the increased levels of PAI, as suggested by our enzymography results and by other clinical observations (34).

PAI levels were found to be significantly higher in patients with septicaemia than in those with local infection, which could be due to the more intense endothelial damage in patients with positive blood cultures. On the other hand, PAI activity was markedly increased in sepsis by gram-negative bacteria, which is not surprising since endotoxin is a cell wall constituent of these bacteria. The PAI levels found in gram-positive septicaemia can be attributed to acute-phase reaction behaviour (35).

The highest PAI concentrations were found in patients with DIC, suggesting a possible role of this inhibitor in the pathogenesis of endotoxin-induced DIC. It is known that thrombin added to confluent monolayers of human endothelial cells induces a six-fold increase in PAI in conditioned medium (36). Interestingly, both endotoxin and thrombin can induce endothelial cell secretion of an interleukin 1-like activity (37). On the other hand, an impairment of clearance from the circulation, via the liver, might also explain the high inhibitor levels in these patients. This would agree with experimental observation of a markedly prolonged half-life of t-PA antigen in endotoxin-treated rabbits after functional hepatectomy (38). Thus, the endotoxininduced release of a fibrinolytic inhibitor together with the suppression of endothelial fibrinolytic activity (26) would contribute to fibrin deposition within blood vessels, a typical finding of DIC.

In conclusion, this study shows that there is a marked increase of PAI in patients with bacterial infections, particularly gramnegative sepsis. Increased PAI levels may contribute to DIC associated with human septicaemia.

\section{Acknowledgements}

This work was supported by Grant $86 / 1222$ from the FIS of the Ministerio de Sanidad y Consumo, Spain. We are grateful to I. Paz and G. Equiza for their expert technical assistance.

\section{References}

1 Morrison D C, Ulevitch R J. The effects of bacterial endotoxins on host mediation systems. A review. Am J Pathol 1978; 93: 526-617.

2 Mizock B. Septic shock. A metabolic perspective. Arch Intern Med 1984; 144: 579-85. 
3 Loskutoff D J. The fibrinolytic system of cultured endothelial cells: deciphering the balance between plasminogen activation and inhibition. In: Progress in Fibrinolysis, Vol 7. Davidson J F, Donati M B, Coccheri S (eds). Churchill Livingstone, Edinburgh 1985; pp 15-22.

4 Nilsson I M, Hedner U, Pandolfi M. Physiology of fibrinolysis. In: Fibrinolysis. Kline D L, Reddy K N N (eds). CRC Press, Inc., Boca Raton, FL 1980; pp 165-83.

5 Verheijen J H, Chang G T G, Kluft C. Evidence for the occurrence of a fast-acting inhibitor for tissue-type plasminogen activator in human plasma. Thromb Haemostas 1984; 51: 392-5.

6 Kruithof E K O, Tran-Thang C, Ransijn A, Bachman F. Demonstration of a fast-acting inhibitor of plasminogen activators in human plasma. Blood 1984; 64: 907-13.

7 Wiman B, Chmielewska J, Ranby M. Inactivation of tissue plasminogen activator in plasma. J Biol Chem 1984; 259: 3644-7.

8 Thorsen S, Philips M. Isolation of tissue type plasminogen activator inhibitor complexes from human plasma. Biochim Biophys Acta 1984; 802: $111-8$.

9 Juhan-Vague I, Moerman B, De Cock F, Aillaud M F, Collen D. Plasma levels of a specific inhibitor of tissue-type plasminogen activator (and urokinase) in normal and pathological conditions. Thromb Res 1984; 33: 523-30.

10 Erickson L A, Ginsberg M H, Loskutoff D J. Detection and partial characterization of an inhibitor of plasminogen activator in human platelets. J Clin Invest 1984; 74: 1465-72.

11 Holmberg L, Lecander I, Persson B, Astedt B. An inhibitor from human placenta specifically binds urokinase and inhibits plasminogen activators released from ovarian carcinoma in tissue culture. Biochim Biophys Acta 1978; 544: 128-37.

12 Dosne A M, Dupuy E, Bodevin E. Production of a fibrinolytic inhibitor by cultured endothelial cells derived from human umbilical vein. Thromb Res 1978; 12: 377-87.

13 Emeis J J, Van Hinsberg V W M, Verheijen J H, Wijngaards G. Inhibition of tissue-type plasminogen activator by conditium medium from cultured human and porcine vascular endothelial cells. Biochem Biophys Res Commun 1983; 110: 392 -8.

14 Levin E G. Latent tissue plasminogen activator produced by human endothelial cells in culture: evidence for an enzyme-inhibitor complex. Proc Natl Acad Sci US A 1983; 80: 6804-8.

15 Sprengers E D, Verheijen $\mathbf{J} \mathbf{H}$, Van Hinsberg V W M, Emeis J J. Evidence for the presence of two different fibrinolytic inhibitors in human endothelial cells conditioned medium. Biochim Biophys Acta 1984; 801: 163-70.

16 Philips M, Juul A, Thorsen S. Human endothelial cells produce a plasminogen activator inhibitor and a tissue-type plasminogen activator-inhibitor complex. Biochim Biophys Acta 1984; 802: 99-110.

17 Van Mourik J A, Lawrence D A, Loskutoff D J. Purification of an inhibitor of plasminogen activator (anti-activator) synthesized by endothelial cells. J Biol Chem 1984; 259: 14914-21.

18 Sprengers E D, Kluft T C. Plasminogen activator inhibitors. Blood 1987; 69: 381-7.

19 Colucci M, Páramo J A, Collen D. Generation in plasma of a fastacting inhibitor of plasminogen activator in response to endotoxin stimulation. J Clin Invest 1985; 75: 818-24.

20 Verheijen J H, Mullaart E, Chang G T G, Kluft C, Wijngaards G. A simple sensitive spectrophotometric assay for extrinsic (tissue-type) plasminogen activator applicable to measurements in plasma. Thromb Haemostas 1982; 48: 266-9.

21 Páramo J A, Alfaro M J, Rocha E. Postoperative changes in the plasmatic levels of tissue-type plasminogen activator and its fast-acting inhibitor. Relationship to deep vein thrombosis and influence of prophylaxis. Thromb Haemostas 1985; 54: 713-6.

22 Loskutoff D J, Mussoni J. Interactions between fibrin and the plasminogen activators produced by cultured endothelial cells. Blood 1983; 62: 62-8.
23 Wiman B, Ljungberg B, Chmielewska J, Urden G, Blomback M, Johnsson $\mathrm{H}$. The role of the fibrinolytic system in deep vein thrombosis. J Lab Clin Med 1985; 105: 265-70

24 Páramo J A, Colucci M, Collen D, Van de Werf F. Plasminogen activator inhibitor in the blood of patients with coronary artery disease. Br Med J 1985; 291: 573-4.

25 Páramo J A, De Boer A, Colucci M, Jonker J J C, Collen D. Plasminogen activator inhibitor (PA-inhibitor) in the blood of patients with deep vein thrombosis. Thromb Haemostas 1985; 54: 725.

26 Crutchley D J, Conanan L B. Endotoxin induction of an inhibitor of plasminogen activator in bovine pulmonary artery endothelial cells. J Biol Chem 1986; 261: 154-9.

27 Emeis J J, Kooistra T. Interleukin 1 and lipopolysaccharide induce an inhibitor of tissue-type plasminogen activator in vivo and in cultured endothelial cells. J Exp Med 1986; 163: 1260-6.

28 Verheijen J H, Sprengers E D, Emeis J J, Van Hinsbergh V W M, Chang $\mathrm{G} T \mathrm{~T}$, Kluft $\mathrm{C}$. Tissue-plasminogen activator inhibition by human endothelial cell conditioned medium. In: Progress in Fibrinolysis, Vol 7. Davidson J F, Donati M B, Coccheri S (eds). Churchill Livingstone, Edinburgh 1985; pp 141-5.

29 Erickson L A, Hekman C M, Loskutoff D J. The primary plasminogen-activators inhibitors in endothelial cells, platelets, serum, and plasma are immunologically related. Proc Natl Acad Sci USA 1985; 82: $8710-4$.

30 Philips M, Juul A G, Thorsen S, Selmer J, Zeuthen J. Immunological relationship between the fast-acting plasminogen activator inhibitors from plasma, blood platelets and endothelial cells demonstrated with a monoclonal antibody against an inhibitor from placenta. Thromb Haemostas 1986; 55: 213-7.

31 Uidén G, Chmielewska J, Carlsson T, Wiman B. Immunological relationship between plasminogen activator inhibitors from different sources. Thromb Haemostas 1987; 57: 29-34.

32 Sprengers E D, Akkerman J W N, Jansen B G. Blood platelet plasminogen activator inhibitor: two different pools of endothelial cell type plasminogen activator inhibitor in human blood. Thromb Haemostas 1986 ; 55: 325-9.

33 Kruithof E K O, Tran-Thang C, Bachmann F. Studies on the release of a plasminogen activator inhibitor by human platelets. Thromb Haemostas 1986; 55: 201-5.

34 Nilsson I M, Ljungner H, Tengborn L. Two different mechanisms in patients with venous thrombosis and defective fibrinolysis: low concentration of plasminogen activator or increased concentration of plasminogen activator inhibitor. Br Med J 1985; 290: 1453-5.

35 Juhan-Vague I, Aillaud M F, De Cock F, Philip-Joet C, Arnaud C, Serradimigni $A$, Collen $D$. The fast-acting inhibitor of tissue-type plasminogen activator is an acute phase reactant protein. In: Progress in Fibrinolysis, Vol7. Davidson J F, Donati M B, Cocheri S (eds). Churchill Livingstone, Edinburgh 1985; pp 146-9.

36 Gelerther T D, Sznycer-Laszuk R. Thrombin induction of plasminogen activator-inhibitor in cultured human endothelial cells. J Clin Invest 1986; 77: 165-9.

37 Bevilacqua M P, Schleff R R, Gimbrone Jr M A, Loskutoff D J. Regulation of the fibrinolytic system of cultured human vascular endothelium by interleukin 1. J Clin Invest 1986; 77: 587-91.

38 Colucci M, Páramo J A, Collen D. Inhibition of one-chain and twochain forms of human tissue-type plasminogen activator by the fastacting inhibitor of plasminogen activator in vitro and in vivo. $\mathbf{J}$ Lab Clin Med 1986; 108: 53-9

Received November 19, 1987 Accepted after revision February 9, 1988 